\title{
Effectiveness of Problem Based Learning to Improve The Results of Learning Indonesian Language
}

\section{Siti Choiriyah}

SDN Karanganyar 01

sitichoi6@gmail.com

\section{Article History}

received 3/12/2020

\begin{abstract}
The focus of this Class Action Research is the application of Problem Based Learning on The Results of Learning Bahasa Indonesia Grade 5 SDN Karanganyar 01 Tugu Subdistrict Semarang Year 2019/2020. From the above formulation of research objectives for (1) Describing the application of the use of PPT media in improving student learning achievement (2) Describing how to improve students' learning motivation, especially the content of Indonesian language lessons. The implementation of learning improvements carried out in three cycles of each cycle shows an improvement in learning outcomes. From the data obtained, it can be concluded that the use of Problem Based Learning on the results of learning Bahasa Indonesia grade 5 SDN Karanganyar 01 Tugu Subdistrict Semarang is very effectively used to improve student learning outcomes.
\end{abstract}

Keywords: problem based learning, Indonesian language, class action research

\begin{abstract}
Abstrak
Fokus Penelitian Tindakan Kelas ini adalah penerapan Problem Based Learning pada Hasil Belajar Bahasa Indonesia Kelas 5 SDN Karanganyar 01 Kecamatan Tugu Semarang Tahun 2019/2020. Dari perumusan tujuan penelitian di atas untuk (1) Menggambarkan penerapan penggunaan media PPT dalam meningkatkan prestasi belajar siswa (2) Menggambarkan bagaimana meningkatkan motivasi belajar siswa, khususnya isi pelajaran bahasa Indonesia. Pelaksanaan perbaikan pembelajaran yang dilakukan dalam tiga siklus setiap siklus menunjukkan peningkatan hasil pembelajaran. Dari data yang diperoleh, dapat disimpulkan bahwa penggunaan Problem Based Learning pada hasil belajar Bahasa Indonesia kelas 5 SDN Karanganyar 01 Tugu Kecamatan Semarang sangat efektif digunakan untuk meningkatkan hasil belajar siswa.
\end{abstract}

Kata kunci: pembelajaran berbasis masalah, Bahasa Indonesia, penelitian tindakan kelas

Social, Humanities, and Education Studies (SHEs): Conference Series https://jurnal.uns.ac.id/shes

p-ISSN 2620-9284 e-ISSN 2620-9292 


\section{PENDAHULUAN}

Pada Era globalisasi ini dunia industri semakin maju dan berkembang yang mengakibatkan ketatnya persaingan dalam memperoleh pekerjaan. Untuk menghadapai tuntutan tersebut, maka kurikulum nasional harus disesuaikan dengan perkembangan zaman dan sesuai yang dibutuhkan pada pendidikan saat ini. Menurut Undang-undang Nomor 20 Tahun 2003 tentang sistem pendidikan nasional, kurikulum adalah seperangkat rencana dan pengaturan, mengenai tujuan, isi, dan bahan pelajaran serta cara yag digunakan sebagai pedoman penyelenggaraan kegiatan pembelajaran untuk mencapai tujuan pendidikan tertentu.

Kurikulum 2013 (K13) adalah kurikulum yang menjadi pilihan untuk menggantikan Kurikulum Tingkat Satuan Pendidikan (KTSP). Kurikulum 2013 bertujuan untuk mempersiapkan manusia Indonesia agar memiliki kemampuan hidup sebagai pribadi dan warga negara yang beriman, produktif, kreatif, inovatif, dan afektif serta mampu berkontribusi pada kehidupan bermasyaraka, berbangsa dan bernegara, dan peradapan dunia (Permendikbud Nomor 70 Tahun 2013 : 7). Muatan pelajaran bahasa Indonesia adalah contoh salah satu muatan pelajaran yang kurang diminati para peserta didik. Dalam mengikuti pembelajaran, anak-anak sering bosan, bahkan kurang minat dengan pembelajaran sebelumnya. Hal ini terlihat dari hasil belajar peserta didik yang rendah terutama pada pelajaran Bahasa Indonesia yang nilainya tuntas KKM hanya 63\%. Sedangkan ketentuan tercapainya pembelajaran apabila mencapai rata-rata nilai harian $75 \%$. Mungkin karena guru hanya ceramah biasa saja tanpa adanya media pembelajaran jadi kurang menarik perhatian peserta didik.

Menurut Hidayat (1986) efektifitas adalah suatu ukuran yang menyatakan seberapa jauh target (kualitas, kuantitas dan waktu) telah tercapai. Dimana makin besar presetase target yang tercapai, makin tinggi efektifitasnya. Dalam pembelajaran diperlukan perancangan yang matang, teknik, model pembelajaran, hingga evaluasi pembelajaran itu berkesinambungan. Perlunya penggunaan model-mdel pembelajaran yang efektif dan inovatif agar dalam pembelajaran yang dilakukan lebih bervariatif dan berjalan lancar. Salah satu indikator efektivitas belajar adalah tercapainya sebuah tujuan pembelajaran. Keterlibatan siswa secara aktif menunjukkan efisiensi pembelajaran. Proses belajar megajar dikatakan efektif jika pembelajaran tersebut dapat mencapai tujuan yang diharapkan serta siswa dapat menyerap materi pembelajaran.

Pada masa pandemi seperti ini guru dituntut untuk melakukan pembelajaran daring (dalam jaringan) karena tidak boleh tatap muka dengan peserta didiknya. Karena di SD saya masyarakatnya menengah ke bawah jadi untuk menggunakan aplikasi-aplikasi seperti zoom meet, google meet dan lain-lain itu masih sulit. Saya dulu pernah menggunakan zoom meeting untuk bisa bertatap maya dengan anak-anak, tapi yang dapat hadir hanya anak 16 dari 40 peserta didik. Ada yang mengatakan hp di bawa orang tua, kemudian ada juga yang mengatakan kuota tidak mencukupi, ada juga yang mengatakan memori handphone sudah penuh. Dari berbagai alasan tersebut saya menggunakan Whatsapp untuk pembelajaran. Untuk modelnya saya mengunakan sintak Problem Based Learning adalah salah satu metode dalam pengajaran teori kognitif dengan mengutamakan peran guru dalalm menciptakan situasi belajar yang melibatkan siswa belajar aktif dan mandiri(Kurikulum 2013 menurut Permendikbud Nomor 22 Tahun 2016).

Menurut Duch (1995) dalam Aris Shoimin (2014:130) mengemukakan bahwa pengertian Problem Based Learning (PBL) atau pembelajaran berbasih masalah adalah model pengajaran yang bercirikan adanya permasalahan nyata sebagai konteks untuk para peserta didik belajar berfikir kritis dan keterampilan memecahkan masalah serta memperoleh pengetahuan. Dari permasalahan yang dipaparkan di atas, maka perlu adanya tindakan dalam mengatasi rendahnya hasil belajar peserta didik. Salah satu tindakan peneliti adalah efektifkah Problem Based Learning terhadap hasil 
belajar Bahasa Indonesia di kelas V SDN Karanganyar 01 Kecamatan Tugu Kota Semarang tahun pelajaran 2019/2020. Rendahnya hasil belajar peserta didik kelas V ini menjadi fokus masalah penelitin tindakan kelas ini. Dalam hal ini peneliti mengajukan solusi dengan sintak Problem Based Learning untuk mengatasi permasalahan pembelajaran. Sintaks Model Pembelajaran Problem Based learning adalah 1) Orientasi peserta didik pada masalah;2) Mengorganisasikan peserta didik untuk belajar;3) Membimbing penyelidikan individu maupun kelompok;4) Mengembangkan dan menyajikan hasil karya; dan5) Menganalisis dan mengevaluasi proses pemecahan masalah.

Tujuan penelitian adalah untuk meningkatkan hasil belajar siswa kelas $\mathrm{V}$ muatan pelajaran Bahasa Indonesia di SDN Karanganyar 01 Kecamatan Tugu Kota Semarang tahun pelajaran 2019/2020.

\section{METODE}

Penelitian ini merupakan Penelitian Tindakan Kelas. Tempat penelitian adalah SDN Karanganyar $01 \mathrm{JL}$. Walisongo KM. 12. Waktu penelitian dibulan April 2020. Subyek penelitian adalah peserta didik Kelas V SDN Karanganyar 01 tahun ajaran 2019/2020 sebanyak 40 anak.

Adapun sumber data diperoleh dari data primer, yaitu data yang diperoleh dari peserta didik, berupa nilai tes tertulis peserta didik dan nilai keterampilan dalam bentuk laporan tugas. Pada tiap siklus dilakukan satu tes dan peserta didik mengumpulkan laporan tugas.Data sekunder, yaitu data yang diperoleh dari pengamatan peneliti dan kolaborator, berupa hasil diskusi dengan kolaborator yang dituangkan dalam tiap-tiap siklus.

Dalam penelitian melaksanakan 3 siklus yaitu siklus I, siklus II dan siklus III. Pengumpulan data menggunakan teknik tes dan non tes. Tes tertulis digunakan pada akhir siklus. Sedangkan Teknik non tes meliputi teknik observasi dan dokumentasi. Observasi digunakan pada saat pelaksanaan penelitian tindakan kelas kemampuan memahami materi pada muatan pelajaran Bahasa Indonesia pada tiap siklus. Alat pengumpulan data meliputi tes tertulis, terdiri atas 10 butir soal pilihan ganda dan non tes meliputi lembar observasi dan dokumen.

Validasi proses pembelajaran dilakukan dengan teknik triangulasi sumber dan triangulasi metode. Sebagai salah satu teknik pengolahan data kualitatif, triangulasi menurut Sugiyono (2011) diartikan sebagai teknik yang bersifat menggabungkan dari berbagai teknik pengumpulan data dan sumber data yang telah ada. Triangulasi sumber dilakukan dengan observasi terhadap subjek penelitian yaitu peserta didik kelas V SDN Karanganyar 01 dan kolaborasi dengan teman sejawat. Triangulasi metode dilakukan dengan penggunaan metode dokumentasi selain metode observasi. Metode dokumentasi digunakan untuk memperoleh data pendukung yang diperlukan dalam proses muatan pelajaran Bahasa Indonesia.

\section{HASIL DAN PEMBAHASAN}

Penelitian ini menggunakan desain penelitian tindakan kelas dari Kurt Lewis(1946). Penelitian Tindakan Kelas adalah penelitian yang dilakukan di dalam kelas menggunakan suatu tindakan untuk meningkatkan kualitas proses belajar mengajar agar diperoleh hasil yang lebih baik dari sebelumnya. Melalui penelitian ini akan dilihat perubahan-perubahan yang terjadi pada peserta didik setelah peserta didik mendapatkan tindakan dalam pembelajaran. Komponen pokok penelitian tindakan terdiri atas empat komponen(Ernest,1996), yaitu: a) perencanaan/ planning, b) tindakan/ acting, c) pengamatan/ observing, d) refleksi/ reflecting. Hubungan keempat komponen tersebut dipandang sebagai satu siklus. Dalam penelitian ini, digunakan tiga siklus. 
Tiap-tiap siklus berisi empat tahap. Tahap perencanaan berupa kegiatan menyusun rancangan penelitian yang berupa rencana pembelajaran, lembar angket, lembar pedoman pengamatan, dan lembar evaluasi kemampuan membaca pemahaman. Tahap tindakan merupakan realisasi dari tindakan yang sudah direncanakan sebelumnya. Tahap ketiga adalah pengamatan, tahap ini dilakukan oleh peneliti sebagai pengajar di kelas dan teman guru senior. Tahap keempat adalah refleksi, yaitu evaluasi yang dilakukan setelah berakhir masa tindakan (mengadakan tes kemampuan membaca pemahaman).

Refleksi peneliti bersama teman sejawat mengadakan refleksi hasil pembelajaran penggunaan model Problem Based Learning melalui muatan pelajaran Bahasa Indonesia. Dalam Kehidupan setiap tindakan yang diberikan selesai dilakukan untuk mengetahui kekurangan dan kelebihan kegiatan pembelajaran. Hasil dari refleksi pembelajaran Siklus III digunakan sebagai pedoman untuk kegiatan tindakan pembelajaran. Namun jika pada Siklus II dan III telah memenuhi indikator keberhasilan sesuai KKM 75 baik secara individual yaitu sudah mencapai 75\% secara klasikal , maka tindakan siklus 3 dihentikan.

Tabel 1. Perbandingan Hasil Belajar Siklus I, Siklus II dan Siklus III

\begin{tabular}{cllllll}
\hline Nilai & $\begin{array}{l}\text { Siklus I } \\
\text { Jumlah } \\
\text { anak }\end{array}$ & $\begin{array}{l}\text { Presentase } \\
(\%)\end{array}$ & $\begin{array}{l}\text { Siklus II } \\
\text { Jumlah } \\
\text { anak }\end{array}$ & $\begin{array}{l}\text { Presentase } \\
(\%)\end{array}$ & $\begin{array}{l}\text { Siklus III } \\
\text { Jumlah } \\
\text { anak }\end{array}$ & $\begin{array}{l}\text { Presentase } \\
(\%)\end{array}$ \\
\hline Tuntas & 25 & 63 & 29 & 74 & 36 & 90 \\
Belum Tuntas & 15 & 37 & 11 & 26 & 4 & 10 \\
Jumlah & 40 & 100 & 40 & 100 & 40 & 100 \\
Rata - rata & 74,6 & & 76.5 & & 80,9 & \\
Nilai Tertinggi & 85 & & 96 & & 100 & \\
\hline
\end{tabular}

Pembelajaran pada siklus I masih banyak hal-hal yang belum dilaksanakan oleh guru secara optimal seperti penggunaan media, bahan ajar yang sesuai sehingga tingkat pemahaman peserta didik terhadap materi ajar masih rendah. Pelaksanaan pembelajarna masih kurang menarik minat peserta didik. Hal ini disebabkan kurang jelasnya penjelasan/instruksi guru kepada peserta didik dalam menyelesaikan tugas. Hasil analisis penilaian menunjukan masih rendahnya pemahaman peserta didik terhadap materi pelajaran. Dari 40 peserta didik yang mendapat nilai tuntas baru 25 peserta didik (63\%) dan 15 peserta didik belum mencapai nilai tuntas (37\%). Dengan demikian penulis merencanakan perbaikan pembelajaran siklus 2 .

Pada pelaksanaan perbaikan pembelajaran siklus II peneliti merencanakan pembelajaran dengan persiapan yang lebih matang.Alat peraga yang digunakan berupa media yang sudah menarik. Analisis penilaian hasil yang lebih baik dari pada perbaikan pembelajaran siklus 1 . Dari 40 peserta didik yang tuntas KKM sebanyak 29 peserta didik (74\%) dan yang belum tuntas 11 peserta didik (26\%). Dari siklus sebelumnya menunujukkan peningkatan hasil beljar peserta didik. Keberhasilan pembelajaran ini disebabkan karena dalam proses pembelajaran guru menggunakan media pembelajaran secara efektif disertai tampilan slide power point dan menggunakan model Problem Based Learning serta penjelasan menggunaka metode pemberian tugas dan LKPD, sehingga dengan tugas yang dirancang akan memperjelas informasi guru. Keaktifan peserta didik dalam mengerjkan tugas kelompok akan meningkatkan pemahaman terhadap materi pembelajaran. Tapi dalam pelaksanaannya kurang maksimal sehingga peneliti harus berlanjut ke siklus III

Pada pelaksanaan perbaikan pembelajaran sikus III peneliti merencanakan pembelajaran dengan persiapan yang lebih matang.Alat peraga yang digunakan 
berupa media serta alat peraga yang sudah menarik dan ditampilkan power point yang menarik pula.

Analisis penilaian hasil yang lebih baik dari pada perbaikan pembelajaran siklus 3. Terlihat dari 40 peserta didik yang tuntas sebanyak 36 peserta didik $(90 \%)$ dan yang belum tuntas hanya 4 peserta didik (10\%). Keberhasilan pembelajaran ini disebabkan karena dalam proses pembelajaran guru menggunakan media pembelajaran secara efektif disertai model pembeljaran Problem Based Learning yang sesuai dan juga tampilan power point yang menarik motivasi [eserta didik. Dalam penjelasan menggunakan metode pemberian tugas dan LKPD, serta penggunaan alat peraga sehingga dengan tugas yang dirancang akan memperjelas informasi guru. Keaktifan peserta didik dalam mengerjkan tugas kelompok akan meningkatkan pemahaman terhadap materi pembelajaran. Terlihat dari pencapaian hasil belajar peserta didik yang mengalami kenaikan.

Bila ketuntasan hasil belajar dalam bentuk diagram, maka dapat dilihat pada diagram di bawah ini :

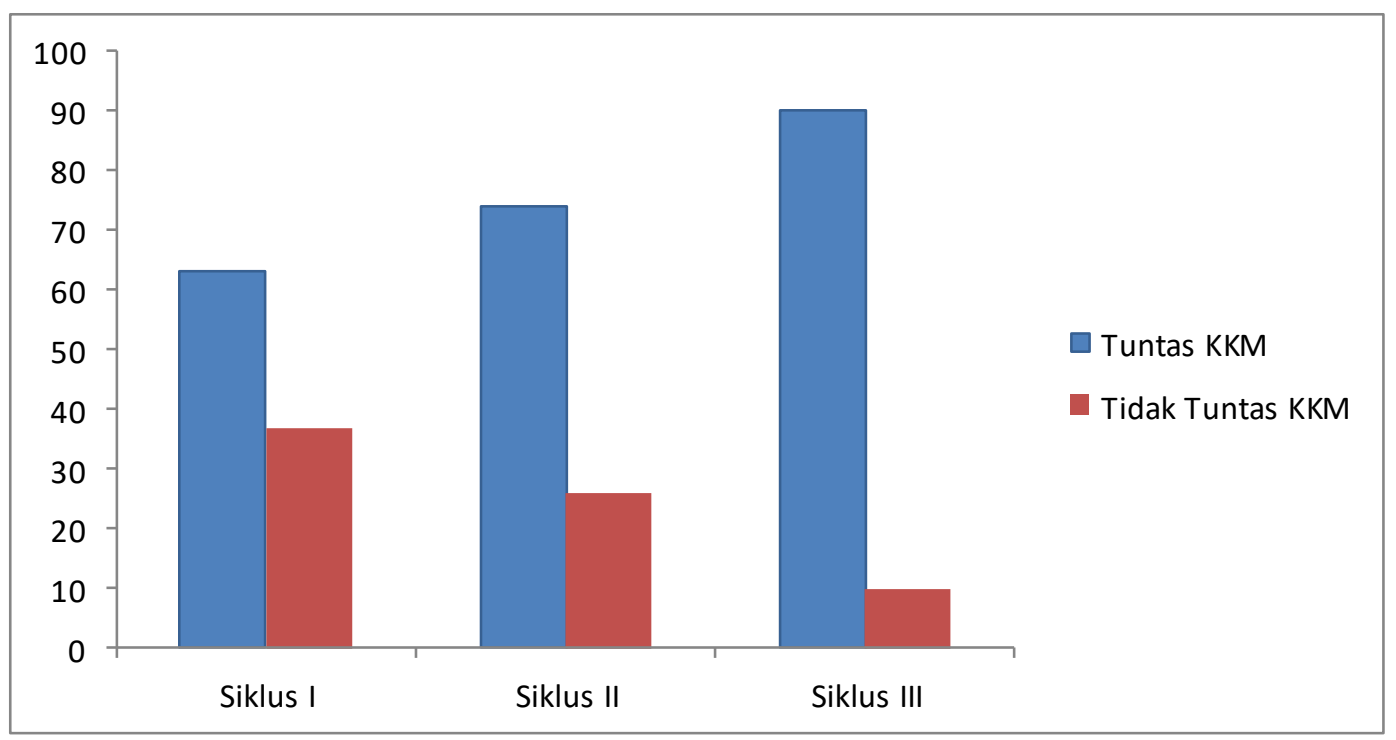

Gambar 1. Grafik Batang Ketuntasan Siklus I, Siklus II,dan Siklus III

Dengan demikian seperti yang dikemukakan dalam kajian teori bahwa pembelajaran akan menyenangkan dan bermakna apabila dalam proses guru terampil dalam memilih dan menentukan metode dan media pembelajan yang disesuaikan dengan materi ajar. Sebagai bukti bahwa pembelajaran itu berhasil adalah adanya evaluasi yang mencapai nilai ketuntasan belajar yang telah ditetapkan pada muatan pelajaran Bahasa Indonesia melalui model Problem Based Learning. Hal ini terbukti dari perolehan tes formatif yang dilaksanakan guru setelah proses pembelajaran selesai.

\section{SIMPULAN}

Berdasarkan hasil yang diperoleh dari Siklus I, Siklus II dan Siklus III terbukti bahwa pembelajaran memerlukan kompetensi yang tinggi dari seorang guru. Salah satunya metode, model dan media pembelajaran yang digunakan harus tepat. Dari beberapa kajian teori mengenai pembelajaran, yang paling menentukan keberhasilan pembelajaran adalah kemampuan guru dalam mengelola pembelajaran. Pengelolaan pembelajaran ini meliputi cara memilih strategi, metode, model dan media yang digunakan dalam pembelajaran. 
Dari hasil penelitian membuktikan bahwa penggunaan model Problem Based Learning sangat efektif digunakan untuk meningkatkan hasil belajar peserta didik khusunya muatan pelajaran Bahasa Indonesia terlihat adanya peningkatan hasil proses belajar peserta didik dati tiap siklus. Penerapan model pembelajaran Problem Based Learning pada peserta didik kelas V SDN Karanganyar 01 adalah dengan hasil akhir nilai rata-rata 80,9 dan persentase ketuntasan $90 \%$. Dengan ini model pembelajaran Problem Based Learning bisa diaplikasikan lagi untuk pembelajaran selanjutnya.

\section{DAFTAR PUSTAKA}

Hidayat. (1986). Konsep Dasar Dan Pengertian Produktivitas Serta Interprestasi Hasil. Jakarta: LP3ES

Kementrian Pendidikan dan Kebudayaan RI. (2013). Peraturan Menteri Pendidikan Pendidikan Dan Kebudayaan Republik Indonesia tentang Kerangka Dasar Dan Struktur Kurikulum Sekolah Menengah Kejuruan/Madrasah Aliyah Kejuruan (Permendiknas Nomor 70). Jakarta:Penulis.

Kementrian Pendidikan dan Kebudayaan RI. (2016). Kurikulum 2013 (Permendikbud Nomor 22 Tahun 2016). Jakarta:Penulis.

Maulid, R. P. 2021. Teknik Triangulasi dalam Pengolahan Data Kualitatif. https://www.dqlab.id/teknik-triangulasi-dalam-pengolahan-data-kualitatif, diakses pada tanggal 9 Maret 2020 jam 13.10

Shoimin, A. (2014). 68 Model Pembelajaran Inovatif Dalam Kurikulum 2013. Yogyakarta: Ar-Ruzz Media

Sunendar, T. (2018). Jenis dan Model Penelitian Tindakan Kelas / PTK. https://www.asikbelajar.com/jenis-dan-model-penelitian-tindakan-kelas-ptk/, diakses pada tanggal 7 Maret 2020 jam 11.00

Syafnidawaty. (2020). Perbedaan Data Primer dan Data Sekunder. https://raharja.ac.id/2020/11/09/perbedaan-data-primer-dan-data-sekunder/, diakses pada tanggal 9 Maret 2020 jam 13.35

Undang-Undang Republik Indonesia Nomor 20 Tahun 2003 Tentang Sistem Pendidikan Nasional. (2003).http://Pendis.Kemenag.Go.Id/File/Dokumen/Uuno20th2003ttgsisdiknas.Pdf, diakses tanggal 7 Maret 2020 jam 11.00

Viandari, E. (2021). Penelitian Tindakan Kelas (PTK). https://www.quipper.com/id/blog/info-guru/penelitian-tindakan-kelas-ptk/, diakses tanggal 9 Maret 2020 jam 10.00 